\title{
Dynamics of carbon cycling by soil bacteria in presence of manganese oxides
}

\author{
ISABELLA OLGA ZELANO ${ }^{1}$, JORGE E. SPANGENBERG ${ }^{1}$, \\ JULIA GONZALEZ HOLGUERA ${ }^{1}$ AND JASQUELIN PENA ${ }^{2}$ \\ ${ }^{1}$ University of Lausanne \\ ${ }^{2}$ University of California Davis \\ Presenting Author: isabella.zelano@unil.ch
}

The accumulation of organic matter in soil (SOM) and its oxidation to $\mathrm{CO}_{2}(\mathrm{~g})$ depends on interactions between organic molecules, mineral surfaces and microbes. Manganese oxides $(\mathrm{MnOx})$ are among the strongest oxidants in soils and play a central role in SOM decomposition. Here, we investigated how the redox reactivity of $\mathrm{MnOx}$ affects carbon consumption by soil bacteria. We compared the kinetics of glucose consumption by Pseudomonas putida KT2440, in the presence and absence of $\delta$ $\mathrm{MnO}_{2}$. We performed kinetic experiments by adding glucose $\left(\delta^{13} \mathrm{C}=-11.41 \pm 0.11 \%\right.$ o) to: i) $\delta-\mathrm{MnO}_{2}$ suspension, ii) P. putida KT2440 suspension, and iii) a mixture of $P$. putida KT2440- $\delta$ $\mathrm{MnO}_{2}$, under controlled conditions $(\mathrm{pH}=7.00 \pm 0.1, t=20 \pm$ $1^{\circ} \mathrm{C}$ ). The reduction of in $\delta-\mathrm{MnO}_{2}$ was tracked by quantification of $\mathrm{Mn}(\mathrm{II})_{\mathrm{aq}}$ and solid-phase $\mathrm{Mn}(\mathrm{III})$. The oxidation of glucose was monitored during six days by the concentrations of oxidation products (i.e., formate, gluconate), dissolved organic carbon (DOC) and the head space concentration and carbon isotope composition $\left(\delta^{13} \mathrm{C}\right)$ of the evolved $\mathrm{CO}_{2}$.

Results showed that under abiotic conditions, DOC content remained constant over time, whereas glucose was oxidized to formate, matching $\mathrm{Mn}(\mathrm{II})_{\mathrm{aq}}$ and $\mathrm{Mn}(\mathrm{III})_{\mathrm{s}}$ concentration, with no $\mathrm{CO}_{2}$ release. Glucose consumption in $P$. putida KT2240 led to full consumption of the DOC after two days and the $\delta{ }^{13} \mathrm{C}-\mathrm{CO}_{2}$ values varied from -23.2 to $-8.4 \%$. In $P$. putida $\mathrm{KT} 2440-\delta$ $\mathrm{MnO}_{2}$ assemblages only half of the total DOC was consumed. However, the abiotically-produced formate was completely consumed after 4 hours and $\delta^{13} \mathrm{C}-\mathrm{CO}_{2}$ values evolved from -28.0 to $-21.9 \%$ during the same time. The $\delta^{13} \mathrm{C}-\mathrm{CO}_{2}$ reached a maximum value of- $6.4 \%$ after 40 hours, and decreased again to $-13.1 \%$ after 4 days.

These results suggest that $\mathrm{MnOx}$ led to the production of small organics that may fuel other bacterial metabolisms, changing bacterial glucose fixation and respiration. 